\title{
Scleroderma renal crisis in a newly diagnosed mixed connective tissue disease resulting in dialysis-dependent chronic kidney disease despite angiotensin-converting enzyme inhibition
}

\author{
Muhammad Abdul Mabood Khalil • \\ Nadia Iftikhar · Syed Ather Hussain • \\ Jackson Tan
}

Received: 28 June 2012/ Accepted: 13 September 2012/Published online: 28 September 2012

(C) Japanese Society of Nephrology 2012

\begin{abstract}
Mixed connective tissue disease (MCTD) is a rheumatic disease with a combination of multiple connective tissue disorders, which includes dermatomyositis or polymyositis, systemic sclerosis, systemic lupus erythematosus, rheumatoid arthritis and Sjögren's syndrome. It affects various organs of the body, which includes the lungs, heart, kidneys, joints, muscles and the haematological system. Here, we report a case of MCTD consisting of scleroderma, Sjögren's syndrome and polymyositis complicated by scleroderma renal crisis (SRC) but with negative anti-nuclear antibody (ANA), anti-Scl 70 and anticentromere antibodies. The patient was started on captopril for the treatment of SRC but developed chronic kidney disease despite adequate blood pressure control with angiotensin-converting enzyme inhibitor (ACEi).
\end{abstract}

Keywords Mixed connective tissue disorder - Sjögren's syndrome $\cdot$ Scleroderma renal crisis $\cdot$ Polymyositis

\author{
Abbreviations \\ MCTD Mixed connective tissue disease \\ SRC Scleroderma renal crisis \\ ACEi Angiotensin-converting enzyme inhibitor
}

M. Abdul Mabood Khalil ( $₫)$ - N. Iftikhar · S. A. Hussain Section of Nephrology, Department of Medicine, Aga Khan University Hospital, Stadium Road, Karachi 74800, Pakistan e-mail: doctorkhali11975@hotmail.com

J. Tan

RIPAS Hospital Brunei Darussalam, Bandar Seri Begawan, Brunei

\section{Introduction}

Mixed connective tissue disease (MCTD) is an overlap syndrome characterised by a combination of connecting tissue diseases, including systemic sclerosis, systemic lupus erythematosus, polymyositis, Sjögren's syndrome and arthritis associated with antibodies to RNA-sensitive extractable nuclear antigen [1]. Clinical features include Raynaud's phenomenon, sclerodactyly, arthritis, inflammatory muscle disease and interstitial lung disease [2]. The typical onset occurs in people over a period of between 15 and 25 years. The anti-U1-ribonucleoprotein (anti-U1-RNP) antibodies are the hallmark of the disease. Other antibodies that can be present include anti-Ro/SS-A, anti-Sm and antidouble stranded DNA antibodies. The diagnosis requires clinical features and serological criteria. We report a case of MCTD with predominant features of systemic sclerosis and Sjögren's syndrome presenting with scleroderma renal crisis (SRC), positive antibodies for MCTD, Sjögren's syndrome and myositis but negative anti-nuclear antibody (ANA), anti-Scl 70 and anti-centromere antibodies.

\section{Case report}

A 44-year-old male presented with a history of blood pressure of 200/100 $\mathrm{mmHg} 3$ days before admission at a local hospital in his native city. Subsequent to that, he developed shortness of breath and vomiting and was transferred to Aga Khan University Hospital, Karachi, Pakistan.

His past history dates back to 2 years, when he had Raynaud's phenomenon, small joints pain, non-healing ulcers at the elbows and thighs, thickening of the skin on his hands and mouth, and dryness of eyes. His previous 
work-up done 2 months back in another hospital showed positive rheumatoid factor (RA factor) and a negative (ANA). His serum creatinine was $158.4 \mathrm{~mol} / \mathrm{l}(1.8 \mathrm{mg} / \mathrm{dl})$. However, he had normal kidney function in April 2011, with a creatinine level of $88.4 \mu \mathrm{mol} / \mathrm{l}(1 \mathrm{mg} / \mathrm{dl}) \mathrm{He}$ was started on prednisolone $40 \mathrm{mg}$ once a day, atenolol $50 \mathrm{mg}$ once a day and hydroxychloroquine $200 \mathrm{mg}$ once a day, which he was taking till this admission.

On presentation to the emergency room, his pulse was $114 /$ min and blood pressure was $170 / 110$. There was skin tightening on his hands, forearms and around the mouth. His jugular venous pressure was raised. There were grade three hypertensive changes on fundoscopy. There were mild oedema and ulcers on his elbows and thighs. Chest examination revealed bilateral fine rales in the lower zone. Cardiovascular examination revealed normal heart sounds but no murmur.

The relevant laboratory investigations on admission were as follows: haemoglobin $9.2 \mathrm{~g} / \mathrm{dl}$, white blood count (WBC) $19.9 / \mathrm{mm}^{3}$, neutrophil $80 \%$, lymphocyte $10 \%$, eosinophil 35 , monocyte $4 \%$, reticulocyte $3 \%$, platelets $243 \times 10^{3} / \mathrm{mm}^{3}$, blood urea nitrogen $35.69 \mathrm{mmol} / 1$ (100 mg/dl), creatinine $813.22 \mathrm{mmol} / \mathrm{l}(9.2 \mathrm{mg} / \mathrm{dl})$, spot urine protein/creatinine ratio 0.8 and creatine phosphokinase $40 \mathrm{IU} / 1$. Peripheral smear revealed anisocytosis, poikilocytosis and fragmented red blood cell. Biochemical analysis showed total bilirubin $1.5 \mathrm{mg} / \mathrm{dl}$, conjugated bilirubin $0.3 \mathrm{mg} / \mathrm{dl}$, unconjugated bilirubin $1.2 \mathrm{mg} / \mathrm{dl}$, alanine transaminase $39 \mathrm{IU} / 1$ and alkaline phosphatase $110 \mathrm{IU} / 1$. His serum lactate dehydrogenase was $210 \mathrm{U} / 1$ and serum haptoglobin was $38 \mathrm{mg} / \mathrm{dl}$. His autoimmune work-up showed positive anti-RNP, anti-topoisomerase I antibody and positive anti-Sjögren's syndrome A antibody. However, ANA, anti-double stranded DNA, anti-Scl 70 and anti-centromere antibodies were all negative. Schirmer's test was suggestive of Sjögren's syndrome. Chest $\mathrm{X}$ ray revealed features of pulmonary oedema. Echocardiography showed an ejection fraction of $35 \%$, with mild pulmonary artery hypertension.

In view of increased WBC, he was started on intravenous piperacillin-tazobactam $2.25 \mathrm{~g}$ every $8 \mathrm{~h}$. He was given intravenous furosemide infusion at $20 \mathrm{mg}$ per hour and captopril $50 \mathrm{mg}$ three times a day because of fluid overload and hypertension. He was started on dialysis on the 3rd day of admission because of persisting pulmonary oedema, deteriorating kidney function and hyperkalaemia. Due to a combination of autoimmune diseases and deteriorating kidney function, his kidney biopsy was done on day 4 of admission. Biopsy showed sclerosis in $2 / 11$ glomeruli and capillary collapse from mild to severe degree in all other glomeruli. Intimal thickness was noted in the wall of blood vessels. The constellation of these findings were suggestive of vasculopathy. Immunofluorescence microscopy revealed no deposition of $\operatorname{IgG}, \operatorname{IgA}, \operatorname{IgM}, \mathrm{C} 3$ and C1q (Fig. 1).

The presence of Raynaud's phenomena, thickened skin, dry eyes and mouth, positive Schirmer's test, and positive anti-SSa/Ro, anti-PM Scl and anti-RNA antibodies pointed to the diagnosis of MCTD. The renal biopsy was consistent with SRC. There was significant loss of kidney function over a short span of time. The patient stayed in hospital for 7 days and, despite good blood pressure control, there was no recovery in renal function. He was discharged on captopril $50 \mathrm{mg}$ three times a day and was advised to continue dialysis three times a week. The patient was regularly followed in the outpatient clinic. Three months following the initiation of dialysis, there was still no evidence of recovery of renal function and the patient remained on regular haemodialysis treatment and captopril (Table 1).
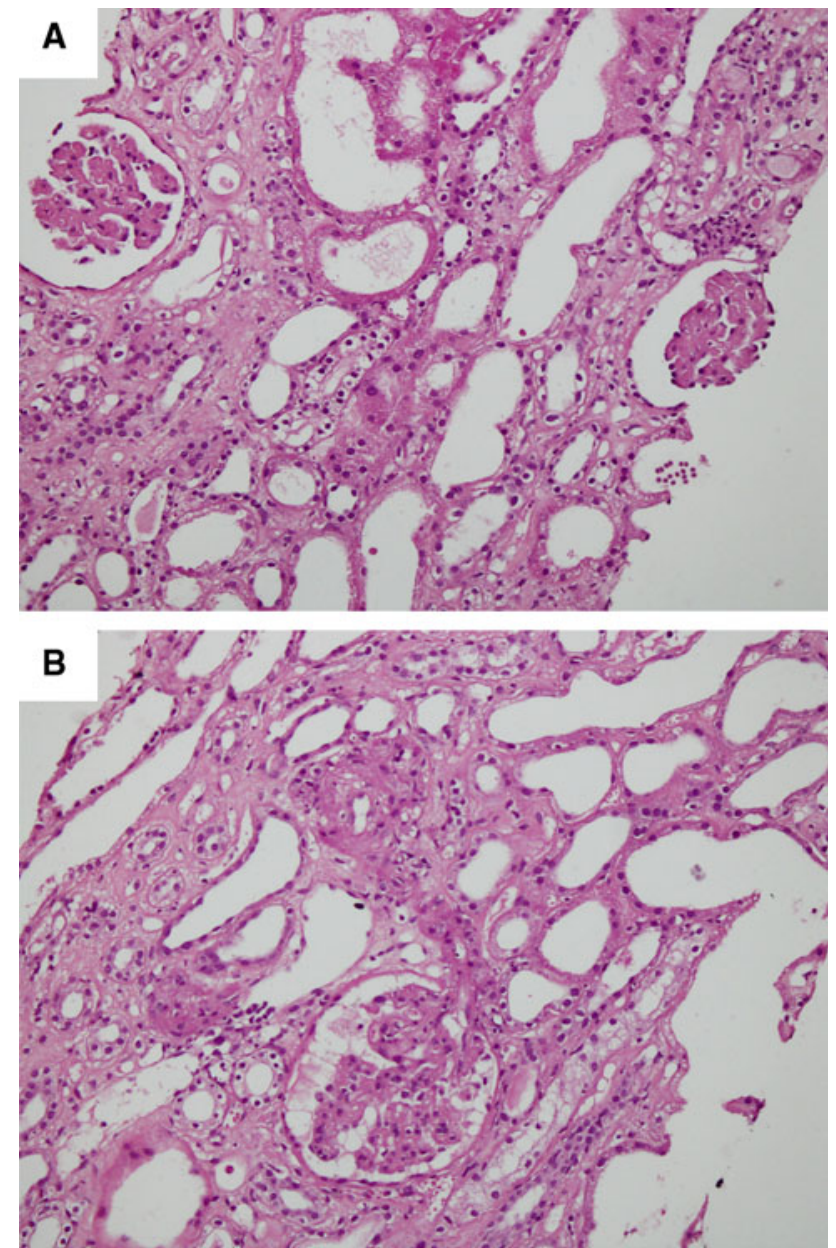

Fig. 1 Biopsy revealed 11 glomeruli (haematoxylin \& eosin staining, original magnification $\times 400$ ). Two glomeruli were sclerosed and the rest showed capillary collapse of varying degree, ranging from mild to severe. Interstitium showed scattered chronic inflammatory cells. Tubules showed focal damage and area of mild atrophy. Blood vessels revealed intimal thickening of their walls. These features were suggestive of vasculopathy 
Table 1 Trend of creatinine and estimated glomerular filtration rate (eGFR) before, during and after admission

\begin{tabular}{|c|c|c|c|}
\hline Date/month & $\begin{array}{l}\text { Serum } \\
\text { creatinine, } \\
\mathrm{mg} / \mathrm{dl}(\mu \mathrm{mol} / \mathrm{l})\end{array}$ & $\begin{array}{l}\text { Blood } \\
\text { pressure } \\
(\mathrm{mmHg})\end{array}$ & eGFR \\
\hline April 2011 (before admission) & $1(88.4)$ & & 79 \\
\hline $\begin{array}{l}16 \text { August } 2011 \text { (before } \\
\text { admission) }\end{array}$ & $1.8(159.12)$ & & 35 \\
\hline 16 October 2011 & $7.3(645.32)$ & $170 / 110$ & 11 \\
\hline 19 October 2011 & $7.7(680.68)$ & $130 / 80$ & 10 \\
\hline $\begin{array}{l}6 \text { November } 2011 \text { (follow-up } \\
\text { after } 2 \text { weeks, the patient } \\
\text { was still on } 3 \text { times per week } \\
\text { dialysis) }\end{array}$ & $9.3(822.12)$ & $125 / 70$ & 8.5 \\
\hline $\begin{array}{l}23 \text { January } 2012 \text { (follow-up } \\
\text { after } 3 \text { months, the patient } \\
\text { was still on } 3 \text { times per week } \\
\text { dialysis) }\end{array}$ & $7.7(680.68)$ & $130 / 80$ & 10 \\
\hline
\end{tabular}

\section{Discussion}

MCTD was defined by Sharp et al. [3] as a combination of at least two of the following three connective tissue diseases: systemic lupus erythematosus, systemic sclerosis and polymyositis. However, there are case reports of five possible combinations of MCTD. Renal involvement in MCTD is not common and renal vascular involvement in MCTD with features of SRC has only rarely been reported [2, 4-6]. Farhey and Hess [7], however, reported that renal involvement can vary between 10 and $50 \%$ in various studies. Besides SRC, renal involvement can be in the form of proliferative glomerulonephritis, membranous glomerulonephritis, amyloidosis or interstitial nephritis.

SRC typically presents with accelerated phase hypertension and progressive renal impairment. Other features may include hypertensive retinopathy, encephalopathy and microangiopathic haemolytic anaemia. Urinalysis reveals non-nephrotic range proteinuria and haematuria [8].

Our patient would have also fulfilled Vancheeswaran et al.'s criteria [9] for SRC (accelerated hypertension, abnormal renal function and fall in creatinine clearance). History of Raynaud's phenomenon, thickened skin, dry eyes and mouth, positive Schirmer's test, positive antiRNA, anti-PM Scl and anti-SSA/Ro antibodies point to the diagnosis of MCTD. Our case was unique because our patient had a negative ANA but a positive anti-U1-RNA antibody.

Renal biopsy, although necessary for diagnosis, is not routinely required in SRC; rather, biopsy is done when doubt exists about the underlying disease or to exclude another concurrent pathological process [10]. Histological manifestation of SRC varied according to the course of disease. Early vascular changes can manifest as intimal accumulation of myxoid material, thrombosis and/or fibrinoid necrosis. Fibrointimal sclerosis with adventitial fibrosis develops later in the course of SRC, causing onion skin-like lesions [10]. Glomerular endothelial cell swelling and thrombosis are the earliest findings, but are very rare [11]. Chronic glomerular changes varied from doublecontour and tram-tracking to ischaemic glomerular collapse $[10,12]$. Chronic changes of SRC on biopsy are, sometimes, difficult to differentiate from changes of scleroderma or systemic sclerosis without SRC; however, the latter group of patients does not develop renal disease requiring dialysis over a mean follow-up of 10 years, as reported by Steen et al. [13]. Chronic kidney disease other than SRC, therefore, seems to have a benign prognosis. In our case, a rapid surge in blood pressure, fall in glomerular filtration rate (GFR), grade 3 hypertensive changes, pulmonary oedema and fragmented red blood smear on blood smear and onion skin-like vasculopathic changes with ischaemic wrinkling of glomeruli and need for dialysis points to the diagnosis of SRC rather than chronic kidney disease due to MCTD.

SRC can be provoked by high blood pressure, anaemia, high-dose steroids medications and cardiac events [14]. Steroids have been consistently found in the literature to precipitate SRC [15-17]. The precipitation of SRC by steroids can potentially result in the loss of GFR in return. Typically, untreated SRC often leads to end-stage renal disease over a period of 1-2 months. The mainstay of treatment is effective blood pressure control with angiotensin-converting enzyme inhibitor (ACEi). Although ACEi have revolutionised the management of SRC, still, quite a significant number of patients end up in long-term dialysis. Penn et al. [17] showed that around $33 \%$ people were still on dialysis at 5 years. Similarly, Steen and Medsger [18] reported permanent dialysis in $19 \%$ of SRC. However, the recovery of renal function can occur following SRC, even after 18 months of crisis [8]. Therefore, the decision regarding renal transplantation should not be made during or immediately following an episode of SRC. In our case, the patient remained on maintenance dialysis and captopril, with no recovery of kidney function 3 months after initial presentation.

There are very few case reports of MCTD with SRC. Table 2 summarises all the studies which reported the presence of SRC in MCTD. Strongwater et al. [6] reported a patient with undifferentiated connective tissue disease with renal failure who responded to enalapril. Andersen and Vasko [19] reported two cases of MCTD having pulmonary and renal insufficiency complicated by SRC which responded to enalapril. They both had features of Raynaud's phenomenon, digital ulcers, and muscle weakness and pulmonary artery hypertension. The second case also had severe polyarthritis and right-sided heart failure. 
Table 2 Summary of case reports of scleroderma renal crisis (SRC) in mixed connective tissue disease (MCTD)

\begin{tabular}{|c|c|c|c|c|c|}
\hline Author & $\begin{array}{l}\text { Journal and year } \\
\text { of publication }\end{array}$ & Country & Study type and size & Main theme & Outcome \\
\hline $\begin{array}{l}\text { Kitridou } \\
\text { et al. [4] }\end{array}$ & $\begin{array}{l}\text { Seminars in } \\
\text { Arthritis and } \\
\text { Rheumatism, } \\
1986\end{array}$ & USA & $\begin{array}{l}\text { Clinicopathological } \\
\text { case series }\end{array}$ & $\begin{array}{l}\text { To assess kidney involvement in } \\
\text { MCTD }\end{array}$ & $\begin{array}{l}11 \text { out of } 30 \text { patients had immune } \\
\text { complex-mediated } \\
\text { glomerulonephritides. Out of } \\
\text { which } 5 \text { had membrane } \\
\text { involvements, } 2 \text { mesangial, } 1 \text { mix } \\
\text { pathology and } 1 \text { had sclerotic } \\
\text { changes. Five out of } 11 \text { developed } \\
\text { SRC. Two out of } 5 \text { became } \\
\text { dialysis-dependent and } 1 \\
\text { developed acute kidney injury }\end{array}$ \\
\hline $\begin{array}{l}\text { Strongwater } \\
\text { et al. [6] }\end{array}$ & $\begin{array}{l}\text { Archives of } \\
\text { Internal } \\
\text { Medicine, } 1989\end{array}$ & USA & Case report & $\begin{array}{l}\text { Patient had undifferentiated } \\
\text { connective tissue disease with } \\
\text { SRC }\end{array}$ & $\begin{array}{l}\text { Patient responded to treatment with } \\
\text { enalapril }\end{array}$ \\
\hline $\begin{array}{l}\text { Andersen } \\
\text { and Vasko } \\
\text { [19] }\end{array}$ & $\begin{array}{l}\text { Clinical } \\
\text { Rheumatology, } \\
2002\end{array}$ & Sweden & Case report $/ 2$ cases & $\begin{array}{l}\text { Both cases had features of } \\
\text { Raynaud's phenomenon, digital } \\
\text { ulcers, muscle weakness and } \\
\text { pulmonary artery hypertension. } \\
\text { The second case also had } \\
\text { polyarthritis and right-sided heart } \\
\text { failure }\end{array}$ & $\begin{array}{l}\text { Both patients responded to } \\
\text { enalapril. However, the second } \\
\text { case died from circulatory } \\
\text { collapse and subsequent autopsy } \\
\text { showed SRC }\end{array}$ \\
\hline $\begin{array}{l}\text { Celikbilek } \\
\text { et al. [20] }\end{array}$ & $\begin{array}{l}\text { Clinical } \\
\text { Rheumatology, } \\
2007\end{array}$ & Turkey & Case report & $\begin{array}{l}\text { Patient developed renal dysfunction } \\
\text { and pulmonary symptoms } \\
\text { following abortion }\end{array}$ & $\begin{array}{l}\text { Patient responded to enalapril, } \\
\text { steroids and immunosuppressive } \\
\text { medications }\end{array}$ \\
\hline $\begin{array}{l}\text { Satoh et al. } \\
\text { [21] }\end{array}$ & $\begin{array}{l}\text { American Journal } \\
\text { of Kidney } \\
\text { Diseases, } 1994\end{array}$ & Japan & Case report & $\begin{array}{l}\text { Patient with inflammatory } \\
\text { myopathy with bilateral carpal } \\
\text { tunnel syndrome who developed } \\
\text { acute kidney injury/SRC }\end{array}$ & $\begin{array}{l}\text { Patient responded to treatment with } \\
\text { angiotensin-converting enzyme } \\
\text { inhibitor and prostaglandin }\end{array}$ \\
\hline $\begin{array}{l}\text { Greenberg } \\
\text { and Amato } \\
\text { [22] }\end{array}$ & $\begin{array}{l}\text { Muscle and } \\
\text { Nerve, } 2001\end{array}$ & USA & Case report & $\begin{array}{l}\text { Patient with inflammatory } \\
\text { myopathy started on steroids and } \\
\text { developed SRC }\end{array}$ & Patient became dialysis-dependent \\
\hline
\end{tabular}

However, despite initial good response in the second case, the patient died of circulatory collapse and, at autopsy, renal biopsy revealed features of SRC.

Celikbilek et al. [20] reported a case of MCTD following abortion complicated by SRC and pulmonary involvement which responded to enalapril, steroids and immunosuppression medications. Satoh et al. reported a female with MCTD with features of Raynaud's phenomenon, sclerodactyly. She was started on low-dose steroids and, 10 months later, presented with increased blood pressure and renal dysfunction. Renal biopsy was consistent with features of SRC. She responded to ACEi and prostaglandins [21]. Similarly, Greenberg and Amato et al. reported a case of SRC in MCTD in a female patient with inflammatory myopathy who was started on high-dose steroids which precipitated SRC, leading to chronic kidney disease stage V. Two months following the SRC episode, she was still dialysis-dependent [22]. From the studies we gathered, there were a total of 11 MCTD patients with SRC, of which 3 became dialysis-dependent [4, 13]. The remaining patients appeared to have responded to ACEi.
Our patient probably did not recover because of late diagnosis, existing chronic kidney disease and failure to start ACEi before admission to our hospital. Steroids aggravate SRC, as evident by various studies [15-17]. Therefore, steroids use, mild chronic hypertension, nonimmunologic mechanism of glomerulonephritis or vasculitis might have resulted in further loss of residual renal functions in our case. Like our case, in Greenberg and Amato's patient [22], SRC occurred following steroids use for myositis, resulting in dialysis-dependent chronic kidney disease. Therefore, patients with MCTD having scleroderma should be vigilantly screened for SRC by the regular monitoring of blood pressure and renal functions. Patients who need steroids should be cautiously watched.

In summary, we would like to add to the growing pool of evidence suggesting that SRC does occur in patients with MCTD. Pre-existing chronic kidney disease and previous exposure to high-dose steroids may have affected our patient's renal recovery. This case confirms that SRC can lead to end-stage renal disease, even with adequate control of blood pressure with ACEi. 
Conflict of interest The authors declare that no conflict of interest exists.

\section{References}

1. De Clerck LS, Meijers KA, Cats A. Is MCTD a distinct entity? Comparison of clinical and laboratory findings in MCTD, SLE, PSS, and RA patients. Clin Rheumatol. 1989;8:29-36.

2. Pope JE. Other manifestations of mixed connective tissue disease. Rheum Dis Clin North Am. 2005;31:519-33.

3. Sharp GC, Irvin WS, Tan EM, Gould RG, Holman HR. Mixed connective tissue disease-an apparently distinct rheumatic disease syndrome associated with a specific antibody to an extractable nuclear antigen (ENA). Am J Med. 1972;52:148-59.

4. Kitridou RC, Akmal M, Turkel SB, Ehresmann GR, Quismorio FP Jr, Massry SG. Renal involvement in mixed connective tissue disease: a longitudinal clinicopathologic study. Semin Arthritis Rheum. 1986;16:135-45.

5. Crapper RM, Dowling JP, Mackay IR, Whitworth JA. Acute scleroderma in stable mixed connective tissue disease: treatment by plasmapheresis. Aust N Z J Med. 1987;17:327-9.

6. Strongwater SL, Galvanek EG, Stoff JS. Control of hypertension and reversal of renal failure in undifferentiated connective tissue disease by enalapril. Arch Intern Med. 1989;149:582-5.

7. Farhey Y, Hess EV. Mixed connective tissue disease. Arthritis Care Res. 1997;10:333-42.

8. Denton CP, Lapadula G, Mouthon L, Müller-Ladner U. Renal complications and Scleroderma renal crisis. Rheumatology (Oxford). 2009;48:iii32-5.

9. Vancheeswaran R, Magoulas T, Efrat G, et al. Circulating endothelin-1 levels in systemic sclerosis subsets-a marker of fibrosis or vascular dysfunction? J Rheumatol. 1994;21:1838-44.

10. Batal I, Domsic RT, Medsger TA, Bastacky S. Scleroderma renal crisis: a pathology perspective. Int J Rheumatol. 2010;2010. pii: 543704.

11. Batal I, Domsic RT, Shafer A, et al. Renal biopsy findings predicting outcome in scleroderma renal crisis. Hum Pathol. 2009;40:332-40.
12. Shanmugam VK, Steen VD. Renal manifestations in scleroderma: evidence for subclinical renal disease as a marker of vasculopathy. Int J Rheumatol. 2010;2010. pii: 538589.

13. Steen VD, Syzd A, Johnson JP, Greenberg A, Medsger TA Jr. Kidney disease other than renal crisis in patients with diffuse scleroderma. J Rheumatol. 2005;32:649-55.

14. Steen VD, Medsger TA Jr, Osial TA Jr, Ziegler GL, Shapiro AP, Rodnan GP. Factors predicting development of renal involvement in progressive systemic sclerosis. Am J Med. 1984;76:779-86.

15. Steen VD, Medsger TA Jr. Case-control study of corticosteroids and other drugs that either precipitate or protect from the development of scleroderma renal crisis. Arthritis Rheum. 1998;41:1613-9.

16. DeMarco PJ, Weisman MH, Seibold JR, et al. Predictors and outcomes of scleroderma renal crisis: the high-dose versus lowdose D-penicillamine in early diffuse systemic sclerosis trial. Arthritis Rheum. 2002;46:2983-9.

17. Penn H, Howie AJ, Kingdon EJ, et al. Scleroderma renal crisis: patient characteristics and long-term outcomes. QJM. 2007;100(8):485-94.

18. Steen VD, Medsger TA Jr. Long-term outcomes of scleroderma renal crisis. Ann Intern Med. 2000;133(8):600-3.

19. Andersen GN, Vasko J. Scleroderma renal crisis and concurrent isolated pulmonary hypertension in mixed connective tissue disease and overlap syndrome: report of two cases. Clin Rheumatol. 2002;21:164-9.

20. Celikbilek M, Elsurer R, Afsar B, Ozdemir HB, Sezer S, Ozdemir NF. Mixed connective tissue disease: a case with scleroderma renal crisis following abortion. Clin Rheumatol. 2007;26:1545-7.

21. Satoh K, Imai H, Yasuda T, Wakui H, Miura AB, Nakamoto Y. Sclerodermatous renal crisis in a patient with mixed connective tissue disease. Am J Kidney Dis. 1994;24:215-8.

22. Greenberg SA, Amato AA. Inflammatory myopathy associated with mixed connective tissue disease and scleroderma renal crisis. Muscle Nerve. 2001;24:1562-6. 